\title{
Language Choice in Swahili Newspaper Advertising in Tanzania
}

\author{
Josephine Dzahene-Quarshie \\ University of Ghana, Legon, Accra-Ghana
}

\begin{abstract}
This paper presents a study on the use of Swahili and English as language choice for advertising in Swahili newspapers in Tanzania. In the literature, it has been posited that bilingual advertising is fast becoming a global trend and that the use of a prestigious L2 (second language) (often English) with a local languages tends to have positive associations for the audience and symbolises modernity and a cosmopolitan identity. In terms of language choice for advertising in Swahili newspapers three trends are observed. Some advertisements are monolingual; Swahili, or English and others are bilingual; Swahili code-switched with English or English code-switched with Swahili. From the data made up of 158 advertisements from 13 issues of three Swahili dailies, this paper examines the choice of language for particular categories of advertisements and discusses the socio-pragmatic factors that may trigger such choice against the claims made by various studies on bilingual advertising. The findings indicate that language choice is largely pragmatically motivated and may be dependent on the type of advertisement, its target audience and to some extent its source.
\end{abstract}

Keywords: language choice, advertising, advertisement, code-switching, bilingual advertisement, newspaper

\section{Introduction}

This paper presents a study on the use of Swahili and English as language choice in advertising in Swahili newspapers in Tanzania. English and Swahili are the two languages that are used for official purposes in Tanzania. Newspapers in Tanzania are published either in Swahili or in English, although the number of Swahili newspapers far exceeds the ones published in English. There are over 50 Swahili newspapers spanning over government owned, private, sports, and entertainment (Kihore, 2004, p. 107). In the Swahili newspapers, the text for all news items is Swahili, but where advertisements are concerned it is observed that both Swahili and English are used either individually or jointly for advertisements. In fact, in terms of language choice, three trends are observed. Some advertisements are monolingual; Swahili, or English and others are bilingual; Swahili code-switched with English or English code-switched with Swahili.

In the literature, the discourse on language choice for advertising indicates that the use of bilingual advertisements has positive associations for the audience and symbolizes sophistication, modernity, and a cosmopolitan identity (Krishna \& Ahluwalia, 2008; Puntoni, de Langhe, \& van Osselaer, 2009; GAO, 2005).

The aim of this paper therefore is to examine the socio-pragmatic factors that may influence language choice in whichever form (that is Swahili only, English only, Swahili with English, or English with Swahili) in Swahili text newspapers and see how far the use of English and Swahili for advertising in Swahili 
newspapers complies with the above claim. This is acheived using a corpus of 158 advertisements from three Swahili dailies.

\section{Discourse on Language Choice in Advertising}

The discourse on language choice in advertising has been a subject of interest not only to linguists but also to experts in marketing and communication as it has serious implications for marketing outcomes besides its pragmatic functions. A look at the literature indicates that as a result of globalization, bilingual and multilingual advertisements are fast becoming the norm all over the world (Gupta, 2007, p. 2; Bhatia \& Ritchie, 2006, p. 525). Often, in advertising in both print and audio-visual media, at least two languages are used; the L1 (first language) of the locality and prestigious L2 (second language) (which most often is the English language). It has been posited that the rise of English has been the most visible effect of the globalization phenomenon (Crystal, 1997; Puntoni et al., 2009, p. 1012; Gupta, 2007, p. 2). This fact re-establishes the claim that English is the language of globalization. For instance, Piller's (2001) data indicated that multi-lingual advertisements accounted for 60\%-70\% of all adverts released on television networks and two national newspapers in Germany in 1999.

Puntoni et al. (2009) and Gupta (2007) further posited that media production exemplifies the growing importance of the English language in advertising. It appears that globally, consumers are routinely addressed by large numbers of marketing messages in English regardless of the fact that English is not their first language (GAO, 2005, p. 827).

The motivations for the use of English in global advertising are many and in fact several theories which have been formulated point to pragmatic and psycholinguistic factors as key. This use of English has also been associated with fetishism (Martin, 2008, p. 155), a notion that involves "the capacity of creating symbolic value-a value greater than it contains” (Marx, 1959, as cited in Kelly-Holmes, 2005, p. 23).

The use of local languages, however, suggests association with respect, a higher level of belongingness, solidarity, pride, nationalism, family, and sensitivity toward the language community. The use of local language on the other hand may be associated with negative connotations of inferiority and lower socio-economic status depending on certain variables (Krishna \& Ahluwalia, 2008; Puntoni, et al., 2009). Language choice in advertising has also been identified as an instrument of identity construction (GAO, 2005, p. 829).

GAO (2005) pointed out that, the use of the language spoken by the group that holds power and prestige which is likely to be English depending on the locality, has positive associations, while the language spoken by those low in power and prestige, may have negative associations, such as inferiority. However, this may vary from one locality to the other.

A growing school of thought holds that even different peoples are basically the same, and that an international advertising campaign with a truly universal appeal can be effective in any market as the trend toward universal advertising themes abroad is accelerating (Fatt, 1967, pp. 60-62). The literature indicates that relatively very little research in this area has been conducted in Africa. This study indicates that while advertisement from multinational companies, such as mobile phone companies tend to be in line with global advertising in terms of language choice strategies, advertising at least in Tanzania by local organisations and individuals are not as sophisticated as those of the developed world. Language choice here tends to be more pragmatically motivated. It must be pointed out that in most of the studies referred to above, the advertisements concerned are mainly advertisements of consumer 
products and luxury. Our study considers a broader spectrum of advertisements. This includes EP (educational publicity), JV (job vacancies), PS (products and services), and PA (public announcements).

\section{Methodology and Data Analysis}

The conclusions drawn from this study are based on the analysis of the data used. The data are made up of advertisements from issues of three popular Swahili daily newspapers, Mtanzania (6 issues), Mwananchi (5 issues), and Tanzania Daima (2 issues) dated between 2006 and 2008. All advertisements in a total of 13 randomly selected issues of the above newspapers numbering 158 were isolated for the study. The advertisements were grouped under four major categories: PA, JV, EP, and PS as illustrated in Table 1.

Table 1

Description and Distribution of Type of Advertisement

\begin{tabular}{|c|c|c|c|}
\hline Type of advert & Description & Number & Percentage (\%) \\
\hline PA & $\begin{array}{l}\text { Tender notices, information on interruption of electricity power supply and } \\
\text { water supply, announcements from public institutions such as government } \\
\text { ministries }\end{array}$ & 53 & 34 \\
\hline JV & Advertised formal or informal JV & 13 & 8 \\
\hline EP & Vacancies for admission into schools, training courses & 12 & 8 \\
\hline PS & $\begin{array}{l}\text { Consumer items and services; used cars, traditional medicine, houses, used } \\
\text { computers, telecommunication services, etc. }\end{array}$ & 80 & 50 \\
\hline Total & & 158 & 100 \\
\hline
\end{tabular}

The statistics of the data, according to the above categorisation in Table 1, indicate that the product and services category make up $50 \%$ of the total of 158 advertisements numbering 80 . This is followed by PA with $34 \%$ of a total of 53 advertisements. JV formed $8 \%$ of a total of 13 advertisements and EP formed $8 \%$ of a total of 12 advertisements.

Clearly more advertisements in these Swahili newspapers target consumers of PS. However, we observe that larger advertisement spaces are used by state-owned institutions, multinational companies as well as private companies for public advertising such as tender notices and PA. Most of the advertisements of the PS category are found in the classified advertisements column referred to in Swahili newspapers by the label Papo kwa Papo ("Here and Now"). Many of them advertise used products such as cars, computers, as well as houses for sale or rent, farms and plots of land. Services such as construction services, water supply services, job opportunities, and vacancies in schools are also found in this column.

In the paper, Swahili only is a label used for advertisements written exclusively in Swahili, Dominant Swahili for those advertisements that have Swahili as the main text interspersed with some English words. English only label refers to advertisements that are written exclusively in English and the dominant English label refers to advertisements that have English interspersed with some Swahili words. Apart from the EP category which does not employ the dominant English category of language choice, each of the categories of advertisements employs all of the four language choices at one time or the other. Table 2 illustrates the distribution of type of advertisement and language choice.

The data indicate that $61 \%$ of the advertisements isolated for the purpose of this study are of mixed texts of Swahili and English. Of these, 90\% are made up of mainly Swahili with English and $10 \%$ are made up of English with Swahili. 
Table 2

Distribution of Type of Advertisement and Language Choice

\begin{tabular}{lccccc}
\hline Type of advert/language choice & English only & $\begin{array}{l}\text { Swahili } \\
\text { only }\end{array}$ & $\begin{array}{l}\text { Dominant } \\
\text { English }\end{array}$ & $\begin{array}{l}\text { Dominant } \\
\text { Swahili }\end{array}$ & Total \\
\hline PA & 20 & 16 & 2 & 15 & 53 \\
JV & 8 & 2 & 1 & 2 & 13 \\
EP & 4 & 1 & 0 & 7 & 12 \\
PS & 6 & 5 & 7 & 62 & 80 \\
\hline Total & 38 & 24 & 10 & 86 & 158 \\
\hline
\end{tabular}

Where single code advertisements is concerned English only advertisements out-number Swahili only advertisements that is $24 \%$ English only as against $15 \%$ Swahili only advertisements. Of the 53 PA the highest number 20 are in English, as against 15 in Swahili. Most JV are entirely in English while most EP advertisements are in Swahili with a few words in English. Most of the product and services advertisements are Swahili codes-witched with English. Figure 1 illustrates the percentages that the various language choices represent.

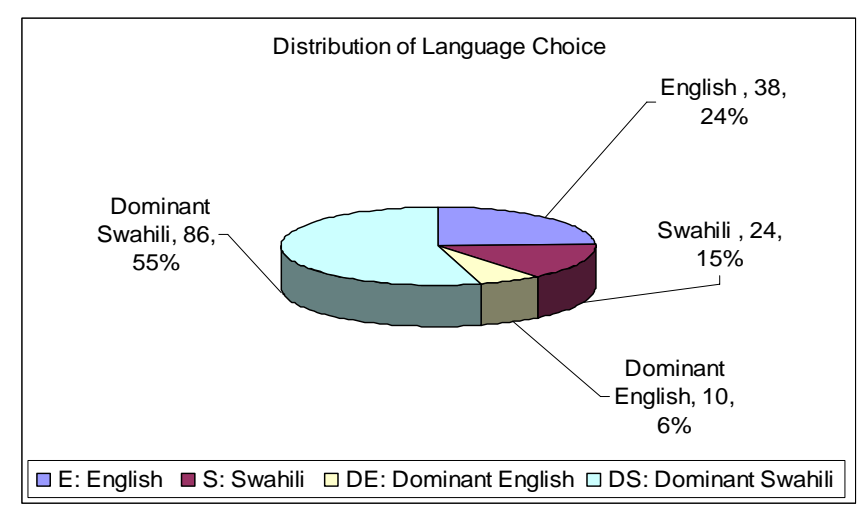

Figure 1. Distribution of language choice.

\section{Discussion}

Kelly-Holmes (2005, p. 2) pointed out that the functioning of advertising text relies on a number of different relationships such as the relationship between the reader, the advertising text and the advertiser. In the same way, it can be argued that the choice of language is also largely dependent on such relationships. The choice of language must be informed by at least the target audience. Language choice may also be informed by the subject matter of the advertisement.

Education in Tanzania can be described as bilingual to some extent with Swahili and English playing different roles at different levels of the education ladder as spelt by the language in education policy. However, what is striking in Swahili newspapers is the fact that it is deemed fit to include English in advertising in these newspapers while in actual fact there are also English newspapers in Tanzania. In the following subsections, the relationship between language choice and type of advert is examined closely.

\section{Language Choice in PA}

The PA category is of two broad types: tender notices and announcements of diverse social issues, such as information on load shedding of electricity supply and interruption of water supply. In the data, English is used 
exclusively for all government tender notices inviting bids for various supplies of stationeries, equipments, and tools to state departments, and the target audiences for these are obviously not the average Tanzanian but private, local or multinational companies or individuals who are conversant with this level of highly technical English. The motivation for the use of English in this category of advertising stems from their objectives on the one hand and the target audience on the other hand. There is certainly no motivation for the use of Swahili as language choice in this case. The fact that the newspaper is published in Swahili does not constitute enough motivation for the use of Swahili for this particular category of advertisement. There seems to be a practical approach to language choice here. It is also plausible that the target audience for English advertisements in Swahili newspapers are not only Swahili-speaking people and bilinguals of Swahili and English but also English-speaking non-Swahili people who may be interested in these advertisements. Below is an example of a tender notice (see Figure 2).

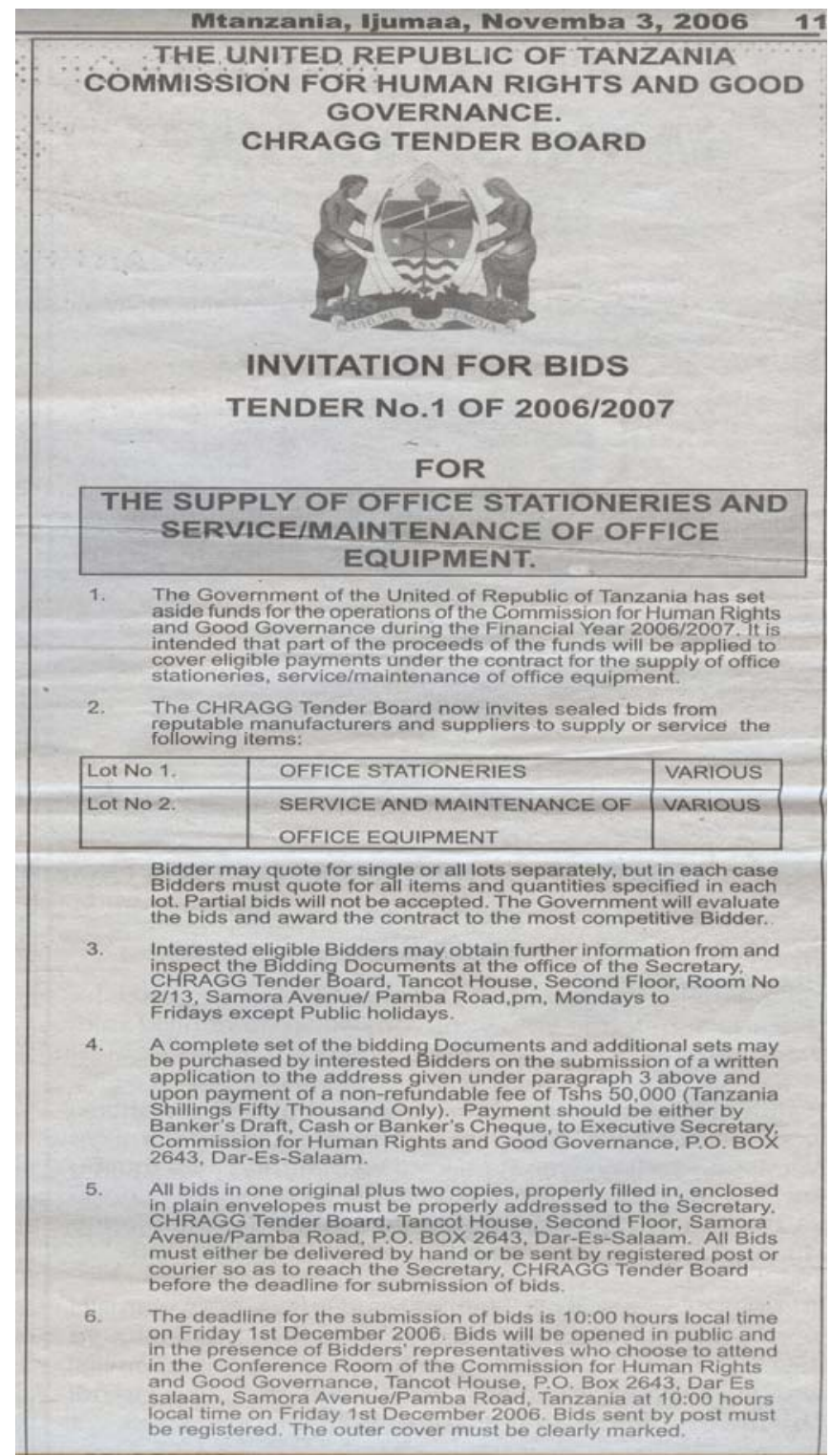

Figure 2. Tender notice. Source: “The United Republic of Tanzania Commission for Human

Rights and good governance. CHRAGG Tender Board”, 2006, p. 11. 
The target audience for the above tender notice, Figure 2 is an exclusive one. They are professional contractors who are used to the language of tenders. This exclusiveness of audience serves as a demotivator for the use of the Swahili language for the general public.

As indicated by Mkilifi (1972), generally official correspondences between different ministries were mostly in English. In such parastatal bodies as the national banks and insurance agencies English are the primary and almost the only language of documentation. PA advertisements of informative category on the contrary are often exclusively Swahili. Although their sources may also be the government or public sector, this time the target audience is the the general citizenry hence the motivation for the use of Swahili as a preferred code. The advertisement below, Figure 3 is an example of such PA advertisements.

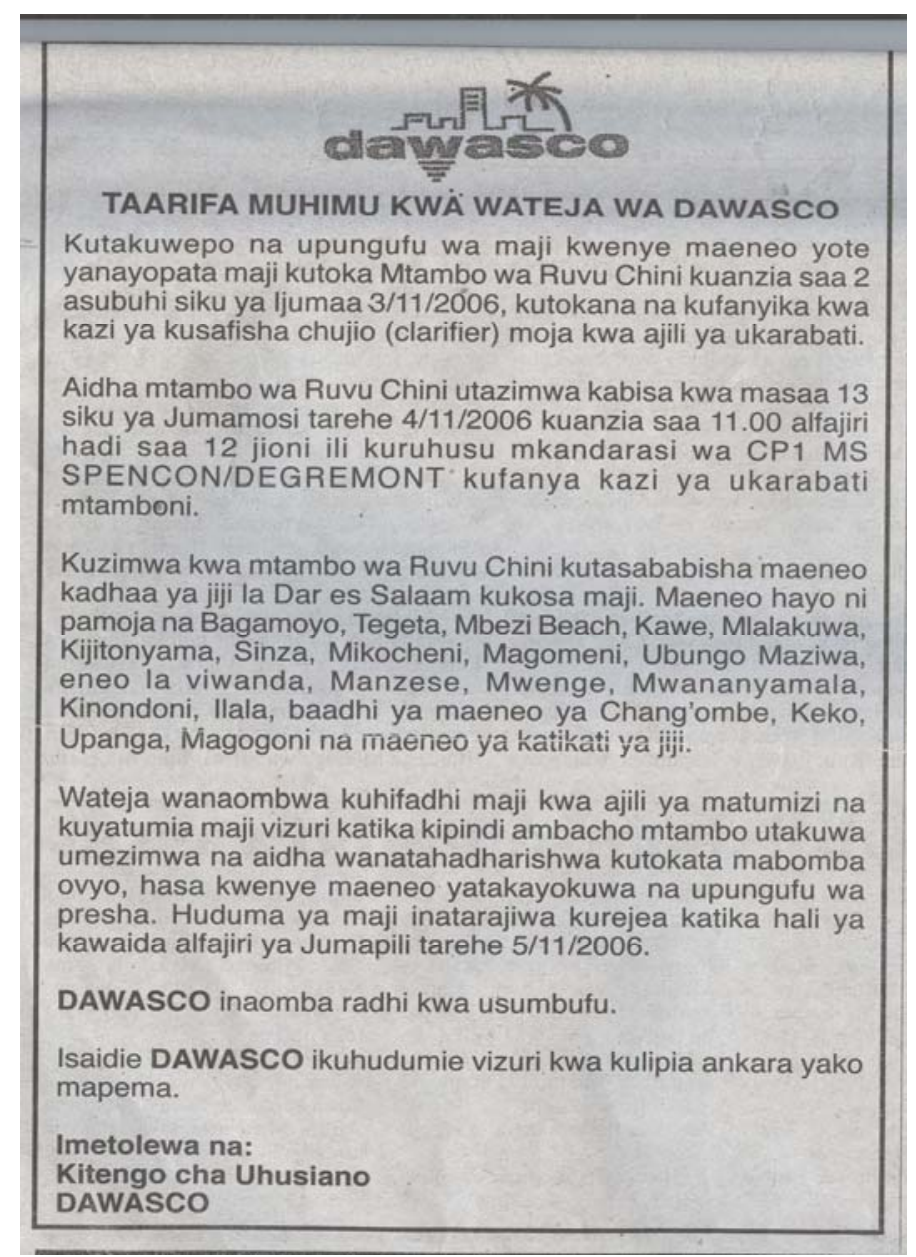

Figure 3. Public announcement. Source: "Important Information for Customars of DAWASCO”

(Taarifa Muhimu kwa Wateja wa DAWASCO), 2006, p. 1.

\section{Dawasco}

Important information for customers of Dawasco

There will be shortage of water in all areas that get water supply from the Ruvu Chini plant from 8.00 on Friday 3/11/2006, due to rehabilitation work on one of the filters.

In addition, the Ruvu Chini plant will be switched off completely for 13 hours on Thursday 4/11/2006 from 5 a.m. until 6 p.m. to allow contractors of CPI MSSPENCON/DEGREMONT to carry out rehabilitation work on the plant. 
The shutdown of the Ruvu Chini plant will result in the shortage of water in several areas in Dar es Salaam.

The areas include Bagamoyo, Tegeta, Mbezi Beach, Kawe, Mlalakuwa, Kijitonyama, Sinza, Mikocheni, Magomeni, Ubungo, Mwenge, Mwananyamala, Kinondoni, Ilala, some areas in Chang’ombe, Keko, Upanga, Magogoni and areas in the city centre.

Customers are requested to store water for their use and use water well during the shutdown period. Also they are cautioned not to leave the taps on anyhow especially in areas where there will be low pressure. Water supply service is expected to resume to normal at dawn on Sunday 5/11/2006.

Dawasco apologizes for the inconvenience.

Help Dawasco to serve you well by paying your bills on time.

Issued by

The Public Relations Department

Dawasco

This announcement is from a water company, Dawasco and it seeks to inform its customers about interruptions to their water supply. The subject of the announcement is "Important for Costumers of Dawasco". There are two similar PAs that are predominantly English. Example 1 is from the TENESCO (Tanzania Electricity Company). It announces a load shedding schedule for a period and lists the affected areas according to zones. The first part of the announcement is in Swahili and it apologises to the public for the load shedding exercise and explains why it had become necessary (some underground cables had been stolen). The English part of the announcement reads:

Example (1)

Schedule of Load Shedding from Ilala Region for

10 days from 18th January to 28th January, 2008... Sat.

19th Jan. 2008, Tue. 22nd Jan. 2008, Fri. 25th Jan. 2008, Mon. 28th

Jan. 2008

TG6 33kV line supplying power to Msasani s/s to be switched

OFF at 19:00 hrs. The line to be switched on at 20:30 hrs. ...

... Shirika linasikitika kwa usumbufu utakaojitokeza

“The cooperation regrets any resulting inconveniences”. (Mtanzania, January 20, 2008, p. 16)

The English part does not offer any explanation to the non-Swahili reading public but does give the most important information, the detailed load shedding schedule in English. The announcement then ends with an apology in Swahili.

It appears then that the primary target audiences for this announcement are bilinguals in Swahili and English and the secondary target audiences are English-speaking non-Swahili public. There is an indication that language choice for advertisements from the same public institutions is dependent on the type of advertisement as well as the target audience as indicated by Kelly-Holmes (2005). However, the notion of fetishism, prestige, modernity and so on discussed in (Krishna \& Ahluwalia, 2008; Puntoni, et al., 2009; GAO, 2005), do not play any significant role in this category of advertising in Swahili newspapers despite the use of English.

\section{Language Choice in JV}

An interesting trend is observed, examining the various job vacancy advertisements. Here again there is a consistency in the relationship between language choice and target audience as well as type of advert. As stated in the section on "Methodology and Data Analysis", of the 13 JV, eight are in English only, two in Swahili only, one 
predominantly English and two predominantly Swahili. Four of the English only advertisements have state institutions; Muhimbili National Hospital, National Audit Service, National Health Insurance Fund, and Institute of Social Work as their source. The others are media companies and a multinational company. The common factor in all these advertisements is that they all advertise high-profile job vacancies and positions; from Director of Medical Services to Finance and Administrative Manager. As a result of the high qualifications sought, no effort is made at all to use Swahili as language choice even though some specify proficiency in both English and Swahili as prerequisites for employment.

On the other hand, for the two JV that are in Swahili in our data, the target audience for one was a clerk for an herbal clinic and the target audience for the other was a Swahili newsreader. For both positions, proficiency in Swahili was a requirement, hence the motivation for Swahili as language choice.

For the bilingual vacancy advertisements that are predominantly Swahili, the main language of the advertisement is Swahili but the positions are written in English and for some, the advertised positions are written in both Swahili and English as in Example 2. The details of the company are also in English. Here again the positions advertised do not require high-level qualifications.

Example (2)

CHUI SECURITY CO. LTD.

P.O. Box 14889, Tel: 022-2448013, Mob: 0748537923

Fax: 0222139087/2400047, Dar es Salaam-Tanzania

NAFASI ZA KAZI

Tunakaribisha maombi ya kazi kwa Raia wa Tanzania na wakazi wa

Dar es Salaam wenyewe sifa na uzoefu unaofaa.

"We invite applications from citizens of Tanzania and residents of

Dar es Salaam with suitable experience"

\section{A. WAKAGUZI/INSPECTORS}

(a) Awe na Elimu ya sekondari kidato cha nne na kuendelea

"should have secondary education up to at least fourth grade"

(b) Awe anajua kuongea na kuandika Kiingereza na Kiswahili

"Should be able to speak amd write Swahili and English"

(c) Awe anajua kuendesha Pikipiki

"Should know how to ride a motorbike"

(d) Awe na uzoefu wa miaka 2 na kuendela

"Should have at least two years' experience"

(e) Awe amepitia mafunzo ya mgambo, Polisi JKT na sifa za ziada

kama anazo

"Should have gone through militia or police training or National Service"

B. WASIMAMIZI/SUPERVISORS

(a) Awe na Elimu ya Msingi, kidato cha nne na kuendelea

"should have primary education up to at least form four"

(b) Awe anafahamu kuongea na kuandika kiingereza na Kiswahili

"Should be able to speak amd write Swahili and English"

(c) Awe na uzoefu wa miaka 2 na kuendelea.

"Should have at least two years' experience"

(d) Awe amepita mafunzo ya Mgambo, JKT au Polisi.

"Should have gone through militia training, national service or police training”. (Mtanzania, November 3, 2006, p. 4) 
This advertisement essentially spells out Tanzanian citizenship as a prerequisite, hence the predominant use of Swahili. The motivation for the English versions of the advertised positions perhaps stems from the fact that the Swahili versions are renditions of standard English terms such as inspector, and supervisor as in the Example 2. Language choice in this category again is pragmatic and is dependent on its suitability to the target audience.

\section{Language Choice in EP}

Most of the advertisements of the EP category are predominantly Swahili code-switched with English and these are usually announcing vacancies for pre-school, primary, or secondary level education. Obviously the target audiences are parents of varied social status.

The use of English exclusively may for instance exclude parents of low social status but somehow standard technical terms such as "high school”, "pre-STD 1", and “'A' Level” are used, it seems out of necessity or for practical reasons. Often some of these English terms are used together with their Swahili counterparts. In other words the English terms are translated into Swahili for those who may not be familiar with the English terms. We observe an extensive use of this strategy in two EP advertisements. One is an advertisement for enrolment into various short courses in media studies and the other is an advertisement for various courses in technical training.

In Example 3, the Swahili terms for "basic", "intermediate”, and "advanced” are quoted in English and Each of the courses on offer is stated first in English then the Swahili version is enclosed in brackets. Some of the Swahili renditions as underlined below are more explanatory and others are more of loan translations. Again others simply give more details about the English terms. This, points to the lack of standard Swahili versions for these English terminologies.

\section{Example (3)}

kozi za mafunzo ya uandishi wa habari katika ngazi ya awali (basic), kati (intermediate) na juu (advanced).

"Training courses in journalism at basic, intermediate and advanced levels".
(a) Basic News Reporting I (Uandishi wa habari ya awali I)
(b) Basic News Reporting II (Uandishi wa habari ya awali II)
(c) Media Law (sheria za magazeti/redio na televisheni)
"Newspapers, radio, and television laws"
(d) Media ethics (Miiko/maadili ya uandisahi wa habari)
"(Regulations/ethics of news writing)"

(e) Public Relations I \& II (Elimu ya mahusiano I \& II)

"(Communication studies)"

(l) Advertising and newspaper marketing (Stadia za kuuza/kupata matangazo na mbinu za kupromoti uuzaji wa magazeti)

strategies)”. (Mtanzania, January 20, 2008, p. 4)

$$
\text { “(selling and marketing skills and newspaper sales promotion }
$$

It appears that the course labels are standard labels originally in English and there is an attempt to translate them into Swahili for those who are in doubt. These advertisements do not represent typical code-switched texts. Rather English and Swahili versions are placed side by side. However, even in some of the Swahili renditions, some English terminologies are unavoidable. 
Advertisements for higher institutions and invitations for scholarship applications to tertiary institutions are all published in English. Also advertisements for English medium secondary schools in neighbouring countries such as Kenya and Uganda are in English. The use of English as language choice for this category of advertisements seems to be motivated by the fact that the medium of instruction for these institutions is English.

\section{Language Choice in PS Category}

Very few advertisements in the product and services category are monolingual; either Swahili only or English only. Rather they are usually bilingual in content. They are often Swahili code-switched with English.

A careful observation of the various advertisements of the PS category that are Swahili code-switched with English reveals that there are two major trends: advertisements of multinational companies on the one hand and those of local companies or individuals. Advertisements of multinational companies are usually written entirely in Swahili, except for the companies' names and their slogans as in Figures 4-5.

\section{Dumisha. Umoja Afrika Mashariki. \\ Tumia SIM kadi yako ya Celtel ukiwa Tanzania, Kenya na Uganda.

Figure 4. A Celtel advertisement. Soutrce: Mtanzania, November 3, 2006, p. 1.

"Maintain. Unity in East Afrika."

"Use your Celtel sim card while in Tanzania, Kenye and Uganda. Celtel Making life better.”

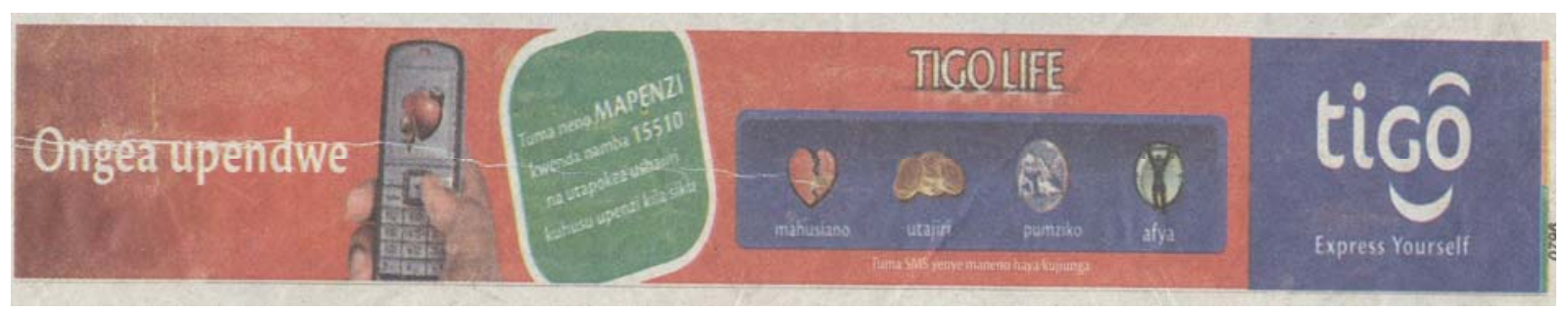

Figure 5. A Tigo advertisement. Source: Mwananchi, November 3, 2006, p. 11.

\footnotetext{
"Chat so you are loved"

"Send a word of love to number 15510 and you will receive advice on love everyday"

"Relationship" "wealth” "rest” "health" "Send a SMS with these words to join.” "Tigo Life” "Tigo Express Yourself.”
}

In these advertisements, Figures 4-5, the companies' names are Celtel and Tigo respectively and their international slogans are respectively “making life better”, “Tigo Life”, and “Tigo Express Yourself”. For the multinational company advertisements, it appears the use of Swahili for the advertising text and English for their international slogans is a noted strategy in the world of advertising. While they want to identify with and reach the Swahili speakers, they also want to make a statement about their international status. They want their PS to be associated with prestige. Thus this is in keeping with global trends in bilingual advertising of consumer products as posited by various scholars in the field (Martin, 2006; Gupta, 2007; GAO, 2005). The 
use of English is therefore deliberate. It is also used to portray a hybrid identity; a feature of modernity that has become a norm in advertising by multinational companies Piller (2001, p. 183).

PS advertisements of local companies and individuals are most often written in Swahili mixed with a few words in English as indicated in Examples 4-5 below, however, in this case the items written in English are usually nouns, adjectives or nouns qualified by adjectives. These may refer to some standard specifications of the items involved or standard terms of description. Language choice here is entirely discretional. It is determined by the individuals and their proficiency in Swahili in terms of the technical terms associated with the commodities being advertised.

Example (4)

BOAT \& ENGINE Yachuma kubwa, full hydrolic system engine

ni marina: HP60 zote zinataka matengenezo, bei sawa na bure mawasiliano 0755162277

"Boat and engine a large yacht, full hydraulic system engine is

Marina: HP60 they all need repairs, the price is right and

free call 0755162277”. (Mwananchi, November 3, 2006, p. 14)

Example (5)

NYUMBA NZURI inauzwa Mikocheni B, vyumba, fensi, self contained vyumba 3 sebule, jiko, dining 0784-882774

"nice house for sale at Michocheni B, rooms, fence,

self contained, three rooms, kitchen, dining 0784-882774”. (Mwananchi, January 26, 2008, p. 22)

In Examples 4-5, the motivation for using some English words is purely pragmatic. The motivation here is certainly different from that of the multinational companies where the use of English or Swahili in a single advertisement is more structured and consciously a deliberate marketing strategy. Although the insertions of English in these predominantly Swahili advertisements may be associated with global trends in bilingual advertising, it is important to note that in these cases of individuals and sometimes small local companies, the use of English in this way may be triggered by different factors. A closer look indicates that language deficiency is one of the major determining factors in language choice. The use of words such as "engine", "full hydraulic", "dining”, "self contained”, "manual”, and "automatic” by individual advertisers are likely to stem from the lack of Swahili equivalents in the individual's Swahili repertoire.

On the other hand, this usage of English may be due to the fact that, for many individuals the English labels are simply more convenient to use. The use of Swahili code-switched with English is rather unmarked. Very few of these advertisements occur in only Swahili or only English. Also, they appear to be quite idiosyncratic, in that each individual chooses which items to be code-switched so that although items that are code-switched with English are to some extent predictable they may differ from individual to individual. Two advertisements that are similar but differ in code-switched items (see Examples 6-7) are listed below to illustrate this point. All the advertisements listed are cited from the Papo Kwa Papo column of the November 3, issue of Mtanzania, 2006.

Example (6)

GARI LINAUZWA —-Toyota Corolla milango 3, linatembea, manual, 5 gears, bei maelewano. 0754906602 "Car for sale-Toyota Corolla three doors, in working condition, manual, five gears, negotiable price. 0754906602” 
Example (7)

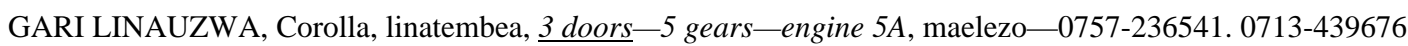

"Car for sale-Corolla, in working condition, three doors-five gears-engine 5A, further information 0754906602"

Examples 6-7 are similar. They advertise the same model of car, Toyota Corolla, and describe them with similar words. They both mention the condition of the car in Swahili and use English for most of the specifications; five gears, manual, and engine 5A. However, in Example 6, "three doors" is written in Swahili milango 3, but in Example 7, the source chooses to use the English equivalent for "three doors".

In comparison, to Examples 6-7, Example 8 advertises a herbal medication for diabetes and sexual weakness. The advertisement is written entirley in Swahili. The use of Swahili exclusively appears to be deliberate. There seems to be no motivation for the use of English for the particular target audience of the advertisement.

Example (8)

Tiba za Asili

“Tomax” Vidonge Asilia

Huongeza Nguvu za kiume, kwa mwanaume ambaye hana uwezo wa kufanya tendo la ndoa (Dk. 90). Pia inatibu kisukari siku 5 tu unapona kabisa hata kama ulishawishi kutumia dawa nyingine bila mafanikio. Fika Mpalaye Herbal Clinic, Magomeni. Mwembechai, Mawasialiano: 0713-967712, 0784-584919

Herbal Treatment

“Tomax” natural capsules

For impotent males, it increases sexual stamina (90 minutes). In addition, it cures diabetes in only five days. You will be healed completely even if you have tried another medicine without any success. Come to Mpalaye Herbal Clinic, Magomeni. Mwembechai, contact: 0713-967712, 0784-584919

\section{Relationship Between Language Choice, Type of Advertisement and Target Audience}

From the above dicussion, it is evidently clear that there is a relationship between the type of advertisement, the target audience and language choice. In other words language choice is to a great extent informed or determined by the type of advertisement and to some extent the target audience. It is evident that English only advertisements are often highly technical in content and target an audience which is familiar with such highly technical texts. The advertisements in question here are usually PA and JV targeting highly educated individuals. Interestingly, the greater majority of Swahili only advertisements are also PA but of informative type such as ones that concern information on electricity and water supply and target the Tanzanian public hence the use of Swahili. Amongst all the four possible language choices for advertising, the dominant English category which is bilingual is the least employed as indicated in Figure 1. There does not seem to be any strong motivation for this language choice. It constitutes a mere $6 \%$ of the total number of advertisements. On the other hand the other bilingual language choice, dominant Swahili is the most used language choice, constituting 55\% of advertisements. Also the dominant Swahili language choice is used predominantly for advertisements of PS, especially the Papo kwa Papo 'classified' category whose target audience is usually the ordinary person. Often the use of some English words in the texts of these advertisements is not intentional, but practical as the advertiser may not know the Swahili equivalent of some items or is used to referring to such items by their English labels. 


\section{Conclusions}

This study has thrown some light on the question of language choice in Swahili newspaper advertising in Tanzania. It has indicated that English plays an important supportive role in information dissemination especially in the area of newspaper advertising. The use of Swahili only or Swahili code-switched with English for locals is purely pragmatic and this makes such advertisements not as sophisticated as those in the developed world. However, the use of Swahili code-switched with English by multinational companies is usually a deliberate marketing strategy in line with current trends in global advertising.

While the use of English in multinational advertisement constitutes a deliberate marketing strategy, the use of English in especially individual advertising does not seem to be deliberate at all but practical. It rather portrays the fact that language alternation involving Swahili and English has become part of the average Tanzanian's diction. Its use here is by default. Nevertheless, it is also not uncommon to observe the use of English versions of some very common items that have widely known Swahili counterparts.

Swahili and English are the two official languages available to Tanzaians on a daily basis and as such the discretion of language choice is the sole prerogative of the advertiser. The fact that a newpaper is a Swahili text one does not constitute enough grounds to exclude the use of English text in it where necessary. Never the less, this liberty begins and ends with advertising. It does not extend to all other news items in the newspaper.

The paper concludes that language choice is strictly non-negotiably Swahili for news items but flexible for advertising. Language choice for advertising is highly dependent on the source of advertisement, type of product or service on the one hand, and the target audience on the other hand. Where there is alternation or switching between the two languages, the nature of switching is also determined to a large extent by the type of advert. The use of bilingual advertising as a tool for persuasion in advertising of consumer products is yet to be a prominent feature in local advertising in Tanzania. There is the need for further studies in this area.

\section{References}

Angermeyer, P. S. (2005). Spelling bilingualism: Script choice in Russian American classified ads and signage. Language in Society, 34, 493-531.

Arthur, C. F. (1967). The danger of “Local” international advertising. Journal of Marketing, 31, 60-62.

Bhatia, T. K., \& Ritchie, W. C. (2006). Bilingualism in the global media and advertising. In T. K. Bhatia \& W. C. Ritchie (Eds.), The handbook of bilingualism (pp. 513-546). Oxford, UK: Blackwell Publishing.

Crystal, D. (1997). English as a global language. Cambridge: Cambridge University Press.

Dzahene-Quarshie, J. (2009). English versus Swahili in Tanzania: The win-win situation. In L. Moshi \& A. Ojo (Eds.), Language pedagogy and language use in Africa (pp. 61-82). London: Adonis \& Abbey Publishers Ltd..

Fatt, A. C. (1967). The danger of "Local” international advertising. Journal of Marketing, 31(1), 60-62.

GAO, L. W. (2005). Bilinguals’ creativity in the use of English in China’s advertising. In J. Cohen, K. T. McAlister, K. Rolstad, \& J. MacSwan (Eds.), Preceedings of the 4th international symposium on bilingualism (pp. 827-837). Somerville, M.A.: Cascadilla Press.

Gupta, R. (2007). Bilingual advertising in a multilingual country. Language in India, 7, 1-14.

Important Information for Customars of DAWASCO (Taarifa Muhimu kwa Wateja wa DAWASCO). (2006, January 20). Mtanzania, p. 1.

Kelly-Holmes, H. (2005). Advertising as multilingual communication. UK: Palgrave Macmillan.

Kiango, J. G. (2005). Tanzania's historical contribution to the recognition and promotion of Swahili. Africa and Asia, 5, 157-166.

Kihore, Y. M. (2004). Grammatical questions in street Kiswahili newspapers-Tanzania (Masuala ya Kisarufi katika Magazeti ya Mitaani ya Kiswahili-Tanzania). Swahili Forum, 11, 107-119. 
Krishna, A., \& Ahluwalia, R. (2008). Language choice in advertising to bilinguals: Asymmetric effects for multinationals versus local firms. Journal of Consumer Research, 35, 692-705.

Ladousa, C. (2002). Advertising in the periphery: Languages and schools in a North Indian city. Language in Society, 31, $213-242$. Martin, E. (2006). Marketing identities through language: English and global imagery in French advertising. UK: Palgrave Macmillan.

Martin, E. (2008). Review of advertising as multilingual communication by Helen Kelly-Holmes. World Englishes, 27(10). 154-157.

Mkilifi, M. H. A. (1972). Triglossia and Swahili-English bilingualism in Tanzania. Language in Society, 1(2), 197-213.

Piller, I. (2001). Identity constructions in multilingual advertising. Language in Society, 30(2), 153-186.

Puntoni, S., de Langhe, B., \& van Osselaer, S. M. J. (2009). Bilingualism and the emotional intensity of advertising language. Journal of Consumer Research, 35, 1012-1025.

Rubagumya, C. M. (1991). Language promotion for educational purpose: The example of Tanzania. International Review of Education, 37(1), 67-85.

Rwezaura, B. (1993). Constraining factors to the adoption of Kiswahili as a language of law in Tanzania. Journal of African Law, 37(1), 30-45.

The United Republic of Tanzania Commission for Human Rights and Good Governance: CHRAGG Tender Board. (2006, November 3). Mtanzania, p. 11

Whitely, W. H. (1969). Swahili: The rise of a national language. London: Methuen

Yung, K. C., \& Gordon E. (2004). The effectiveness of comparative advertising in Korea and the United States: A cross-cultural and individual-level analysis (pp. 75-87). Journal of Advertising, 33(4). Retrieved from https://www.cia.gov/library/publications/the-world-factbook/print/tz.html 